\title{
PROBLEMY ZASAD KLASYFIKACJI ODPADÓW ORGANICZNYCH
}

\section{PROBLEMS CONCERNING ORGANIC WASTE CLASSIFICATION}

http://dx.doi.org/10.12775/PPOS.2014.032

\section{STRESZCZENIE}

Wejście Polski do Unii Europejskiej wiązało się z przystosowaniem prawa krajowego do wymogów praw unijnego. Jednym z najważniejszych działów prawa ochrony środowiska, który został znacząco zmieniony, była gospodarka odpadami. Podstawowym aktem prawnym związanym z gospodarką odpadami jest ustawa o odpadach z dnia 14 grudnia 2012 r. (Dz.U. 2013, poz. 21). Rozporządzenie Ministra Środowiska z dnia 27 września 2001 r. w sprawie katalogu

Magister inżynier, Uniwersytet Przyrodniczy w Poznaniu, Wydział Rolnictwa i Bioinżynierii, Instytut Inżynierii Biosystemów, Studium Doktoranckie.

*** Magister inżynier, Uniwersytet Przyrodniczy w Poznaniu, Wydział Rolnictwa i Bioinżynierii, Instytut Inżynierii Biosystemów, Studium Doktoranckie.

***** Magister inżynier, Uniwersytet Przyrodniczy w Poznaniu, Wydział Rolnictwa i Bioinżynierii, Instytut Inżynierii Biosystemów, Studium Doktoranckie. 
odpadów współgrające z wyżej wypisaną ustawą pozwala podzielić odpady na 20 grup wg źródeł powstawania. W artykule omówiono problemy związane z klasyfikacja odpadów organicznych, mając na uwadze przede wszystkim dwa powyżej przytoczone akty prawne.

\section{Słowa kluczowe} padów.

Gospodarka odpadami; odpady organiczne; aspekty prawne od-

\section{ABSTRACT}

Poland's accession to the European Union required the adjustment of the Polish national law to the strict legislation of the EU. One of the most important areas of environmental protection, significantly changed, was waste management. The basic legal act related to waste management is the Waste Management Act of 14 December 2012 (Journal of Laws 2013, item 21). The regulation of the Minister of Environment of 27 September 2001 on waste catalogue corresponding with the Waste Management Act allows to divide waste into 20 groups according to the source of origin. This paper discusses problems concerning organic waste classification, taking into account two above mentioned legal documents.

\section{Keywords}

Waste management; organic waste; legal aspects of waste.

\section{WSTĘP}

Jednym z najważniejszych zadań, przed którym stanęła Polska po wejściu do Unii Europejskiej, było dostosowanie obowiązującego prawa krajowego do rygorystycznych wymogów wspólnoty. Wdrożenie przepisów dotyczyło wielu różnych dziedzin, w tym i ochrony środowiska [Rudnicki i in. 2011], ze szczególnym uwzględnieniem szeroko rozumianej gospodarki odpadami [Kropiewnicka 2012].

Najważniejszym krajowym aktem prawnym dotyczącym odpadów jest ustawa o odpadach z dnia 14 grudnia 2012 r. 
(Dz.U. 2013 poz. 21 z późniejszymi zmianami). Ustawa ta zaczęła obowiązywać od 23 stycznia 2013 roku, zastępując poprzednią z 27 kwietnia 2001 r. (Dz.U. 2001 Nr 62 poz. 628). Powodem uchylenia wspomnianej ustawy była konieczność implementacji unijnego aktu prawnego, jakim była Dyrektywa Parlamentu Europejskiego i Rady 2008/98/WE w sprawie odpadów oraz uchylająca niektóre dyrektywy z dnia 19 listopada 2008 r. Wprowadzone zmiany w ustawie z 2012 roku w sposób znaczący wpłynęły na cały proces gospodarowania odpadami, pozostawiając jednak pewien zakres bez zmian w stosunku do wersji z 2001 roku. W ustawie określono środki oraz instrumenty, które służyć mają ograniczeniu negatywnego oddziaływania na środowisko, życie oraz zdrowie ludzkie, które może wynikać z wytwarzania oraz zagospodarowania odpadów.

$\mathrm{Z}$ tego między innymi względu zawarto $\mathrm{w}$ ustawodawstwie krajowym wymogi wielu dyrektyw unijnych, nadając im szczegółowe wytyczne. W rozporządzeniu Ministra Środowiska z dnia 27 września 2001 r. w sprawie katalogu odpadów (Dz.U. 2001 nr 112 poz. 1206) przedstawiono wszystkie powstające odpady z podziałem na grupy, podgrupy oraz rodzaje według źródeł ich powstawania. Tak wybrany sposób podziału odpadów jest jednym z wielu możliwych. Rodzi się jednak wątpliwość, czy na pewno jest to sposób najlepszy z punktu widzenia nie tylko prawa, ale również praktyki w życiu codziennym oraz $\mathrm{w}$ badaniach naukowych. Pamiętać należy, że nie zawsze opracowane regulacje prawne ułatwiają działanie podmiotom gospodarczym czy organom administracji publicznej mającymi w praktyce bezpośredni kontakt z tym problemem.

Gospodarka odpadami rozpatrywana być musi w szerokim kontekście, ponieważ sposób postępowania nimi może stymulować bądź spowalniać dążenie do idei zrównoważonego rozwoju [Biegańska i Ciuła 2011]. Dlatego ważna jest znajomość metod klasyfikacji odpadów, co w dalszym procesie spowoduje właściwy sposób ich zagospodarowania [Szuma 2012].

W prezentowanym artykule omówiono sposób klasyfikowania wg krajowego ustawodawstwa specyficznej grupy odpadów, jaką stanowią odpady organiczne. Ponadto autorzy podjęli się próby oceny funkcjonowania tego rozwiązania w praktyce. 


\section{DEFINICJA I WŁAŚCIWOŚCI ODPADÓW ORGANICZNYCH}

W myśl ustawy o odpadach z dnia 14 grudnia 2012 roku pod pojęciem odpadów należy rozumieć „każdą substancję lub przedmiot, których posiadacz pozbywa się, zamierza się pozbyć lub do których pozbycia się jest obowiązany". Analizując powyższą definicję, z całą pewnością można stwierdzić, że jest ona mało precyzyjna i pozostawia szerokie możliwości interpretacji. Najlepszym tego dowodem jest fakt, iż ta sama rzecz może być przydatnym czy wręcz cennym substratem, a dla innej osoby czymś zbędnym, by nie powiedzieć problemowym.

Chcąc mówić o prawnych aspektach klasyfikacji odpadów organicznych, należy określić ich definicje. Już w tym momencie pojawia się problem braku w polskim ustawodawstwie definicji dla tej specyficznej frakcji odpadów. Mając to na uwadze, trudno jest klasyfikować odpady organiczne, nie znając rozwinięcia samego terminu. Mimo tego wyróżnić można kilka wspólnych cech, pozwalających odróżnić odpady organiczne od innych grup odpadów.

Najważniejszą z nich jest zawartość materii organicznej (MO). Jako wartość minimalną najczęściej uznaje się 50\% MO w suchej masie. Parametr ten jest o tyle istotny, że w przypadku nie poddania tej grupy odpadów biologicznemu przetworzeniu (np. produkcja kompostu) zuboża się ekosystem w materię organiczną [Kucharczak i in. 2010]. Drugą równie istotną cechą odpadów jest stosunkowo wysoki stopień ich wilgotności [Ministerstwo Środowiska 2008], co jest równoznaczne z niższą zawartością suchej materii. Przykładem odpadów organicznych może być gnojowica (płynna mieszanina odchodów zwierzęcych), która zawiera minimum 75\% materii organicznej przy poziomie 7-11\% suchej masy [Łucka, Kołodziej, 2011]. Wybrane odpady organiczne przedstawiono na rycinach 1 i 2, przy czym należy pamiętać, że nie wszystkie odpady będą charakteryzowały się tymi cechami. Jako przykład można podać wybrane odpady z przemysłu papierniczego, charakteryzujące się dużym procentowym udziałem materii organicznej, jak i suchej

3/2014 masy [Michniewicz i Janiga 2011]. 


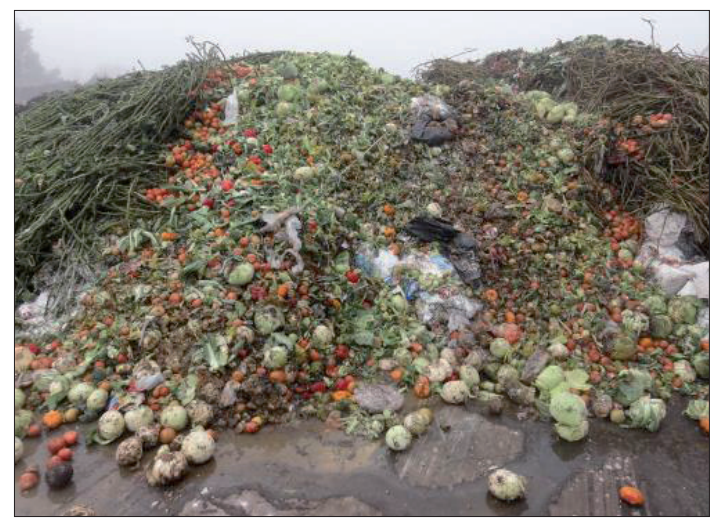

Rycina 1. Odpady z przemysłu warzywniczego [Źródło własne]

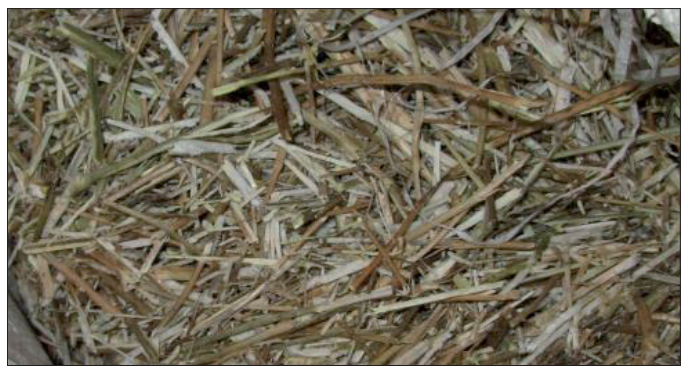

Rycina 2. Słoma [Źródło własne]

Z praktycznego punktu widzenia aspekt gospodarki odpadami organicznymi stanowiącymi znaczny odsetek całości odpadów komunalnych jest istotny dla przedsiębiorców oraz organów administracji. Problem ten przybrał szczególnego znaczenia po nowelizacji ustawy z dnia 1 lipca 2011 r. o zmianie ustawy o utrzymaniu czystości i porządku w gminach oraz niektórych innych ustaw. Wynikło to ze wzrostu obowiązków, który przypadł zarówno samorządom, jak i podmiotom odbierającym odpady.

Wprowadzenie definicji odpadów organicznych mogłoby być istotne z praktycznego punktu widzenia. Należało by jednak podać ściśle kryteria pozwalające zaklasyfikować dane odpady do tej grupy. Pozostałości posiadające podobne właściwości, takie jak uwilgotnienie, mogłyby być zbierane razem, jeśli możliwymi byłoby ich wspólne przetworzenie. 
Najbardziej zbliżoną i często używaną zamiennie definicją dla odpadów organicznych jest termin „odpady ulegające biodegradacji”. Odnosi się on do tych odpadów, które ulegają rozkładowi tlenowemu lub beztlenowemu przy udziale mikroorganizmów [ustawa o odpadach z dnia 14 grudnia 2012 r.]. Rozkład tlenowy to nic innego jak kompostowanie, czyli degradacja substancji (odpadów) organicznych pod wpływem mikroorganizmów, zachodząca z wydzieleniem dużych ilości ciepła [Czekała i in. 2013]. Rozkład beztlenowy zachodzi natomiast w wyniku procesu fermentacji kiedy to odpady organiczne bądź substraty celowe (np. kiszonka z kukurydzy) pod wpływem mikroorganizmów beztlenowych przetwarzane są na biogaz oraz pozostałość zwaną pofermentem [Czekała i in. 2012], będącym cennym nawozem rolniczym. Biorąc pod uwagę aspekt biologicznego przetwarzania odpadów, mniej istotne jest źródło ich pochodzenia. Ważna jest natomiast odpowiednia zawartość substancji organicznej, jako niezbędny substrat do uzyskania odpowiednio dobrego kompostu czy biogazu [Goliński i Joks 2007].

Można więc stwierdzić, że pojęcia odpadów organicznych oraz substancji ulegających biodegradacji są do siebie zbliżone, chociaż i tutaj można doszukać się wyjątków. Dobrym tego przykładem mogą być zrębki drzew iglastych, które charakteryzują się wysoką zawartością materii organicznej, a zarazem stosunkowo trudno ulegają rozkładowi pod wpływem mikroorganizmów. Oznacza to, że z jednej strony są dobrym odpadem organicznym (wysoka zawartość materii organicznej), z drugiej strony odpadem słabo podlegającym biodegradacji.

\section{ZASADY KLASYFIKACJI ODPADÓW ORGANICZNYCH}

Bez wątpienia jednym z najważniejszych elementów prawidłowej gospodarki odpadami jest ich właściwa klasyfikacja. To właśnie pewnego rodzaju skategoryzowanie pozwalające wydzielić pozostałości o podobnych właściwościach, korzyst-

3/2014 nie wpłynie na możliwość ich unieszkodliwienia bądź podda- 
nia procesowi odzysku. Stąd tak ważną rolę odgrywa właściwy dobór wszelkich kryteriów, według których odpady będziemy klasyfikować. Wśród podstawowych wymogów klasyfikacyjnych wydzielić możemy przede wszystkim te fizykochemiczne, biologiczne oraz technologiczne. Na ich podstawie można m.in. wyróżnić klasyfikacje odpadów oparte o:

- źródło pochodzenia odpadów,

- właściwości fizyczne,

- właściwości chemiczne,

- stan skupienia,

- toksyczność,

- stopień zagrożenia dla ludzi i środowiska,

- stopień ich przetworzenia.

W Polsce popularną jest jednolita klasyfikacja, pozwalająca przyporządkować odpady do 27 grup. Co prawda nie jest ona jednak obowiązująca z prawnego punktu widzenia, ale jej głównym kryterium jest substrat bądź gałąź gospodarki, z której to odpady powstały.

Aktem wykonawczym do ustawy o odpadach pozwalającym klasyfikować wszystkie odpady jest rozporządzenie Ministra Środowiska z dnia 27 września 2001 r. w sprawie katalogu odpadów. Regulacja ta jest zbudowana z dwóch zasadniczych części:

a) katalogu odpadów,

b) klucza do klasyfikowania odpadów.

Katalog odpadów dzieli wszystkie odpady według źródeł ich powstawania. Każdy rodzaj odpadów oznaczy jest 6 cyfrowym kodem. Dwie pierwsze cyfry oznaczają grupę, cztery cyfry określają podgrupę, a wszystkie sześć cyfr charakteryzuję rodzaj odpadu. Katalog ten wyróżnia dwadzieścia grup, tj. o siedem mniej w porównaniu do Jednolitej Klasyfikacji Odpadów. Przy podziale w pewnym stopniu pominięte zostały właściwości chemiczne oraz fizyczne odpadów, co ma jednak duży wpływ na klasyfikacje odpadów organicznych, które powstają w bardzo zróżnicowanych miejscach. Problem ten jest zauważalny szczególnie na poziomie grupy, czyli najwyższej z trzech jednostek klasyfikacyjnych. Nadmienić również należy, że podgrupy i rodzaje również nie uwzględniają w sposób znaczący właściwości 
odpadów. Kwestie te można omówić np. na wybranych odpadach organicznych nadających się do biologicznego przetwarzania (Tabela 1). Ta szeroko rozumiana grupa obejmuje większość odpadów organicznych.

Tabela 1. Odpady organiczne nadające się do biologicznego przetwarzania

\begin{tabular}{|c|l|}
\hline $\begin{array}{c}\text { Kod } \\
\text { grupy }\end{array}$ & \multicolumn{1}{c|}{ Grupy odpadów } \\
\hline 02 & $\begin{array}{l}\text { Odpady z rolnictwa, sadownictwa, upraw hydroponicznych, } \\
\text { rybołówstwa, leśnictwa, łowiectwa oraz przetwórstwa żywności. }\end{array}$ \\
\hline 03 & $\begin{array}{l}\text { Odpady z przetwórstwa drewna oraz z produkcji płyt i mebli, } \\
\text { masy celulozowej, papieru i tektury. }\end{array}$ \\
\hline 04 & Odpady z przemysłu skórzanego, futrzarskiego i tekstylnego. \\
\hline 15 & $\begin{array}{l}\text { Odpady opakowaniowe; sorbenty, tkaniny do wycierania, mate- } \\
\text { riały filtracyjne i ubrania ochronne nie ujęte w innych grupach. }\end{array}$ \\
\hline 19 & $\begin{array}{l}\text { Odpady z instalacji i urządzeń służących zagospodarowaniu } \\
\text { odpadów, z oczyszczalni ścieków oraz z uzdatniania wody pitnej } \\
\text { i wody do celów przemysłowych. }\end{array}$ \\
\hline 20 & $\begin{array}{l}\text { Odpady komunalne łącznie z frakcjami gromadzonymi selektyw- } \\
\text { nie. }\end{array}$ \\
\hline
\end{tabular}

Źródło: [Jędrczak 2007]

Przykładowym odpadem ulegającym naturalnemu rozkładowi (biodegradacji) mogą być liście drzew (Ryc. 3) [Niewinna 2010]. W przypadku klasyfikacji wg właściwości i cech wspólnych można by je klasyfikować do jednej grupy bądź podgrupy.

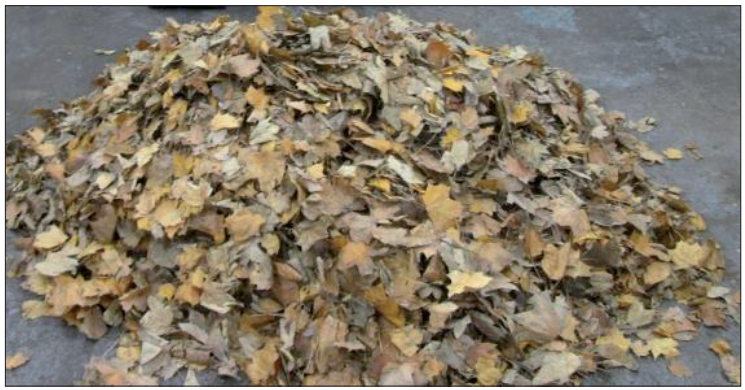

Rycina 3. Liście zebrane na terenie kampusu Uniwersytetu Przyrodniczego w Poznaniu [Źródło własne] 
W przypadku istniejącej klasyfikacji, której kryterium jest źródło powstawania, liście można umieścić w następujących podgrupach:

- 0201 - odpady z rolnictwa, sadownictwa, upraw hydroponicznych, leśnictwa, łowiectwa i rybołówstwa;

- 0203 - odpady z przygotowania, przetwórstwa produktów i używek spożywczych oraz odpady pochodzenia roślinnego, w tym odpady z owoców, warzyw, produktów zbożowych, olejów jadalnych, kakao, kawy, herbaty oraz przygotowania i przetwórstwa tytoniu, drożdży i produkcji ekstraktów drożdżowych, przygotowania i fermentacji melasy (z wyłącz. 02 07);

- 0301 - odpady z przetwórstwa drewna oraz z produkcji płyt i mebli;

- 2001 - odpady komunalne segregowane i gromadzone selektywnie (z wyłącz. 15 01);

- 2003 - inne odpady komunalne.

Z powyższego zestawienia wynika, że ten sam substrat można zaklasyfikować do minimum pięciu grup. Takie postępowanie wynika oczywiście z faktu, że liście mogą pochodzić z wielu źródeł, przez co ich klasyfikacja odbywa się analogicznie w kilku podgrupach, niezależnie od podobieństw charakteryzujących ich skład, czy właściwości chemiczne, które niezależnie od miejsca powstawania będą identyczne bądź zbliżone. Dla potrzeb nauk ścisłych źródło pochodzenia odpadu nie jest tak bardzo istotne, chyba że w badaniach dokonuje się np. porównania właściwości substratów pochodzących z różnych miejsc ich wytwarzania.

\section{ODMIENNOŚCI NA LINII PRAWO A PRAKTYKA}

Powszechnie wiadomo, że na styku nauk prawnych, przyrodniczych i technicznych często powstaje sporo niespójności a nawet kontrowersji. Wynika to przede wszystkim z charakteru pracy oraz podejścia do problemu przedstawicieli każdej z wymienionych nauk. Dlatego też niezmiernie ważnym zada- 
niem jest nakreślenie problemu w taki sposób, który umożliwi kompleksowe podejście do zagadnienia i będzie zrozumiały dla wszystkich ze stron. W ustawodawstwie krajowym za podstawowe kryterium klasyfikacji odpadów przyjęto źródło ich pochodzenia. Oprócz tego wyróżniono te odpady, które uznawane są jako niebezpieczne. Przedstawione rozwiązanie jest $\mathrm{z}$ pewnością najprostszym z możliwych, gdyż pozwala zaklasyfikować odpady w myśl tak zwanej metody od ogółu do szczegółu. Jego celowość może być wyjaśniona również tym, że pozwala podmiotom wytwarzającym bądź zbywającym odpady skategoryzować je w sposób prosty i zazwyczaj jednoznaczny.

Z punktu widzenia nauk ścisłych przydatnym byłoby klasyfikowanie odpadów nie tylko ze względu na ich źródło pochodzenia ale również na podstawowe ich właściwości fizykochemicznych. Takie podejście wynika z faktu, że w badaniach naukowych to właściwości poszczególnych substancji mówią o stopniu ich stabilizacji i możliwych drogach przetworzenia. Dlatego też odpady organiczne stanowią specyficzną grupę, która powinna być wyraźnie wyodrębniona w katalogu odpadów. Ich zasadniczą właściwością jest to, że mogą podlegać dalszym przemianom i rozkładowi na drodze biodegradacji. W praktyce przedsiębiorca bądź podmiot przetwarzający odpady nie musi wiedzieć, skąd dokładnie pochodzi substrat. Ale powinien znać dokładnie jego właściwości. To z kolei pozwala upewnić się, że można go poddać przetworzeniu bądź stabilizacji oraz określić z dużym prawdopodobieństwem skalę ewentualnych ryzyk z tym faktem związanych, które mogą negatywnie wpłynąć na przebieg procesu bądź zanieczyścić środowisko.

W naukach przyrodniczych klasyfikacje według pewnych właściwości są bardzo popularne. Jako doskonały przykład można przedstawić podział biopaliw na stałe, ciekłe i gazowe. I w tym przypadku nie ma znaczenia substrat i proces $\mathrm{w}$ wyniku którego powstało biopaliwo. Nacisk kładzie się natomiast na właściwości i przydatność do danego procesu. 


\section{WNIOSKI}

W przypadku wydzielenia osobnej grupy dla odpadów organicznych możliwa byłaby łatwiejsza ich klasyfikacja, a dany odpad (np. liście) nie byłby klasyfikowany w kilku grupach.

W ustawodawstwie krajowym brak wytycznych pozwalających jednoznacznie oddzielić odpady organiczne od pozostałych. W przypadku istnienia takich kryteriów można by spodziewać się udogodnień w klasyfikacji, a następstwie i w zagospodarowaniu tych odpadów.

Mając na uwadze fakt, że odpady organiczne stanowią tylko część całości wytwarzanych odpadów, należy uznać klasyfikację wg źródeł powstawania za słuszną.

\section{BIBLIOGRAFIA}

Biegańska J., Ciuła J., Zintegrowana gospodarka odpadami komunalnymi w Polsce jako element zrównoważonego rozwoju, „Archiwum Gospodarki Odpadami i Ochrony Środowiska" 2011, Nr 1.

Czekała W., Pilarski K., Dach J., Janczak D., Szymańska M., Analiza możliwości zagospodarowania pofermentu z biogazowni, „Technika Rolnicza Ogrodnicza Leśna" 2012, Nr 4.

Czekała W., Witaszek K., Rodriguez Carmona P. C., Grzelak M., Instalacje do przemystowego kompostowania bioodpadów, „Technika Rolnicza Ogrodnicza Leśna" 2013, Nr 2.

Goliński P., Jokś W. Wtaściwości chemiczne i biologiczne traw i produkcja biogazu, „Łąkarstwo w Polsce” 2007, Nr 10.

Jędrczak A., Biologiczne przetwarzanie odpadów, Warszawa 2008.

Kropiewnicka M., Zasady odbioru i gospodarowania odpadami komunalnymi na gruncie znowelizowanej ustawy o utrzymaniu czystości i porządku w gminach, „Przegląd Prawa Ochrony Środowiska” 2012, Nr 4.

Kucharczak K., StępieńW., Gworek B., Kompostowanie odpadów komunalnych jako metoda odzysku substancji organicznej, „Ochrona Środowiska i Zasobów Naturalnych" 2010, Nr 42.

Łucka I. A., Kołodziej A. U., Rolnicze wykorzystanie masy pofermentacyjnej z biogazowni rolniczej, Koszalin 2011. 
Michniewicz M., Janiga M., Możliwości wykorzystania biomasy lignocelulozowej - produkcja odnawialnych paliw i chemikaliów, „Przegląd papierniczy" 2010, Nr 12.

Ministerstwo Środowiska, Wytyczne dotyczące wymagań dla procesów kompostowania, fermentacji, i mechaniczno-biologicznego przetwarzania odpadów, Warszawa 2008.

Niewinna M., Wielkość opadu i tempo rozkładu ściótki $w$ wybranych drzewostanach Bieszczadów, „Roczniki Bieszczadzkie” 2010, Nr 18.

Rudnicki M., Haładyj A., Sobieraj K. (red.), Dekada harmonizacji w prawie ochrony środowiska, Lublin 2011.

Szuma Karolina, $Z$ problematyki zbierania i magazynowania odpadów, „Przegląd Prawa Ochrony Środowiska” 2012, Nr 3.

Kontakt e-mail:

wojciech@up.poznan.pl 